\title{
Inspection of the actions of veterinarians qualified to act in the National Programme for Control and Eradication of Animal Brucellosis and Tuberculosis
}

\author{
Fiscalização das ações de médicos veterinários habilitados para atuar \\ no Programa Nacional de Controle e Erradicação da Brucelose e \\ Tuberculose Animal
}

\begin{abstract}
Alba Luisa Pereira Ribeiro Said', Fábio Raphael Pascoti Bruhn², Edna Lopes ${ }^{3}$, Christiane Maria Barcellos Magalhães da Rocha ${ }^{3}$, Joziana Muniz de Paiva Barçante ${ }^{3}$, Ana Paula Peconick ${ }^{3}$, Stela Márcia Pereira ${ }^{3 *}$
\end{abstract}

\begin{abstract}
The inspection of qualified professionals is an important action of the National Programme for Control and Eradication of Animal Brucellosis and Tuberculosis (PNCEBT). The data for this study were obtained by compiling reports of 63 inspections in loco of qualified private veterinarians between 2008 and 2011 in the state of Espírito Santo, Brazil. Through the findings of this study, it was observed that all inspected professionals are regularly registered in the CRMV-ES, nevertheless it was found pending issues regarding the registration to conduct vaccinations against brucellosis. It was observed that most professionals keep the infrastructure and equipment for conducting tuberculosis and brucellosis tests. The majority adopts the official models of certification, however there is a significant delay in sending reports of actions, and many professionals reported a lack of demand for certification of properties.
\end{abstract}

KEYWORDS: animals; animal diseases; prevention \& control.
RESUMO: A fiscalização de profissionais habilitados é uma importante ação do Programa Nacional de Controle e Erradicação da Brucelose e Tuberculose Animal (PNCEBT). Com este trabalho, buscou-se reunir informaçóes das fiscalizaçôes relativas à habilitação de médicos veterinários privados no estado do Espírito Santo. Os dados deste estudo foram obtidos mediante a compilação dos relatórios de 63 fiscalizaçôes in loco entre 2008 e 2011. Por meio dos achados deste estudo, observouse que todos os profissionais fiscalizados estão regularmente inscritos no CRMV-ES, todavia foram verificadas pendências quanto ao cadastro para realizar vacinaçóes contra brucelose. Observou-se que a maior parte dos profissionais mantém a infraestrutura e os equipamentos para a realizaçáo de exames de brucelose e tuberculose. A maioria adota os modelos oficiais de atestados, contudo há um expressivo atraso no envio dos relatórios de açôes, e muitos profissionais relataram falta de demandas para certificação de propriedades.

PALAVRAS-CHAVE: animais; doenças dos animais; prevenção $\&$ controle. 


\section{INTRODUCTION}

Brazil presents itself as one of the largest producers and exporters of cattle beef, however this position is often threatened by limitations related to economic indicators, production cost, tariff restrictions and, in a special way, by the occurrence of certain diseases (Rubin et al., 2008; Araújo et al., 2012). Among them, it is highlighted brucellosis caused by Brucella abortus and tuberculosis caused by Mycobacterium bovis, which are widespread throughout the country, forming a significant risk to the production of beef cattle and milk (BraziL, 2006b).

The National Programme for Control and Eradication of Animal Brucellosis and Tuberculosis (Programa Nacional de Controle e Erradicaşão da Brucelose e Tuberculose Animal PNCEBT) was established in 2001 by the Ministerial Normative Instruction $\mathrm{n}^{\circ} 1$ of January 10,2001 . Its purpose is to reduce the prevalence and incidence of bovine and buffalo brucellosis and tuberculosis, as well as certify properties that offer to consumers products with low health risk. The certification process is performed with the test of all animals, associated with the disposal of the reactors until obtaining the status of free herd in three consecutive tests in a minimum period of nine months.

One of the strategies of this program is to enable veterinarians of the private sector to act after training by the Ministry of Agriculture, Livestock and Supply (Ministério da Agricultura, Pecuária e Abastecimento - MAPA next to farms in specific actions contained in the Technical Regulation of the Program, approved by the Normative Instruction $\mathrm{n}^{\circ} 6$, of January 8,2004 . The functions of these professionals include:

1. execution of routine diagnostic tests for brucellosis (buffered acidified antigen (ATT) and Milk Ring Test) and routine and confirmatory tests for tuberculosis in bovine and buffaloes;

2. to take technical responsibility for the health process of the properties, aiming at the certification of the property as free or monitored for brucellosis and tuberculosis;

3. marking the positive animals or reagents to diagnostic tests for brucellosis and tuberculosis with the letter "P", according to the Technical Regulations of the PNCEBT;

4. initiate the arrangements for the proper disposal of positive animals, in accordance with the applicable law, whether for stamping out or destruction;

5. comply with the Technical Regulation of PNCEBT and other supplementary rules established by the Department of Animal Health and the animal health service of the State where it was qualified (BrazIL, 2004).

In state of Espírito Santo, as in the rest of the country, the success of PNCEBT and the credibility of its results are directly linked to the actions of monitoring and supervision of the official veterinary service of the departments of Agriculture of the states, as certifying agency for quality and supervising of the veterinarians actions of the private sector.
Thus, the present work aimed to bring together, for the first time, information regarding inspections of qualifying private veterinarians, performed between 2008 and 2011 in the state of Espírito Santo, aiming to profile and explore its relevant points in order to support the MAPA and the executing agencies in the states of this strategic action of PNCEBT.

\section{MATERIALS AND METHODS}

Espírito Santo has 82 veterinarians regularly qualified to act on PNCEBT whose supervision actions are shared between the Inspection and Animal Health Service and the Federal Superintendence of Agriculture, Livestock and Food Supply (Superintendência Federal de Agricultura) - SISA/DDA/SFA-ES and Institute of Agricultural and Forestry Defense of the Espírito Santo (Instituto de Defesa Agropecuária e Florestal - IDAF.

The data in this study were obtained by compiling reports of all inspections made between 2008 and 2011. Thus, in this period, 63 inspections of veterinarians authorized to act in PNCEBT were conducted, which corresponds to $76.80 \%$ of the authorized veterinarians present in Espírito Santo between 2008 and 2011, coordinated by the Federal Agricultural fiscal agents of SFA-ES and performed by veterinarians of the IDAF-ES. Standard forms were sent to the veterinarian in charge of the Local Veterinary Unit (UVLs) in the cities where the test rooms of qualified professionals were located, with instructive for its completion.

In these records, it were raised aspects of professional identification, physical verification, verification of procedures for vaccination, diagnosis of brucellosis and tuberculosis, certification of properties and final opinion, based on the Normative Instruction $\mathrm{n}^{\circ} 30$ of 2006 and the Technical Manual PNCEBT (BrAZIL, 2006a; 2006b).

\section{RESULTS AND DISCUSSION}

The World Organization for Animal Health (OIE) has highlighted the necessity of improving the legal framework and resources of veterinary services, aiming to provide them with adequate infrastructure, resources and capabilities that enable the countries to benefit fully from the international zoosanitary agreements, while providing greater protection to public and animal health, in order to reduce the threat and spread of diseases to other countries. Furthermore, the OIE considers veterinary services as a global public issue, and should follow the International standards of structure, organization, resources, capacity and actions of professional associates (OIE, 2012).

Thus, in the present study, which evaluates the Brazilian animal health system, when analyzing the certification forms, it was found that 22 of the qualified veterinarians reported no 
information about their home address $(5.80 \%)$ and/or electronic adress $(8.13 \%)$ or telephone $(9.14 \%)$. It is important to highlight that these informations, although not compulsory, are important for the identification of the professionals and control of the official state agency of animal health defense.

Regarding the examination rooms, the majority $(48.76 \%)$ shared them, with only 4 (6.00\%) changing the locations of the examinations, and, in 1 case, the professional's examination room was off. It is important to highlight that, although for the maintenance of the qualification is not compulsory the registration with the Brazilian state, this is a condition that must be sought by professionals to perform vaccinations. However, it was found that $2(3.00 \%)$ professionals had pending issues regarding this register. Nevertheless, all the qualified professionals were properly registered with the Regional Council of
Veterinary Medicine of Espírito Santo - CRMV-ES (Conselho Regional de Medicina Veterinária), and the majority (54.86\%) is registered in other federal units (Table 1).

It was observed that two professionals (3.00\%) were linked to the federal public service (Table 1), and one is approved to teach classes in federal institutions and one is qualified to emit Transit Animal Guides for horses. This demonstrates that few professionals have other forms of involvement with animal health beyond the qualification for vaccination in PNCEBT.

In the present study, it was observed that most of the interviewed have the minimum infrastructure to perform the tests, as well as computers with internet access in good working condition. Most veterinarians (32.51\%) did not have a climatized room thermometer, and $4(6 \%)$ lacked a source of indirect illumination (Table 2). Only 1 (2\%) did not have a stopwatch

Table 1. Identification of veterinarians qualified to serve on the National Programme for Control and Eradication of Animal Brucellosis and Tuberculosis in forms of supervision conducted by the Institute of Agricultural and Forestry Defense of Espírito Santo state, Brazil, between 2008 and 2011.

\begin{tabular}{|c|c|c|c|c|}
\hline \multirow{2}{*}{ Observed items } & \multicolumn{2}{|c|}{ Compliant } & \multicolumn{2}{|c|}{ Non compliant } \\
\hline & n & $\%$ & n & $\%$ \\
\hline Registry of vaccinations & 61 & 97 & 2 & 3 \\
\hline Situation in CRMV-ES & 63 & 100 & 0 & 0 \\
\hline Address & 58 & 92 & 5 & 8 \\
\hline Phone & 54 & 86 & 9 & 14 \\
\hline Email address & 55 & 87 & 8 & 13 \\
\hline Address of the examination room & 59 & 94 & 4 & 6 \\
\hline Sharing of infrastructure & 15 & 24 & 48 & 76 \\
\hline Qualification in other Federal Units & 9 & 14 & 54 & 86 \\
\hline Linkage to federal service & 61 & 97 & 2 & 3 \\
\hline
\end{tabular}

Compliant: Regular status at the Institute of Agricultural and Forestry Defense of the Espírito Santo (IDAF), based on the Normative Instruction $\mathrm{n}^{\circ} 30$ of 2006 and the Technical Manual of PNCEBT (Brazil, 2006a; 2006b); Non compliant: Irregular situation in IDAF; CRMV-ES: Regional Council of Veterinary Medicine of Espírito Santo.

Table 2. Infrastructure available to veterinarians qualified to serve on the National Programme for Control and Eradication of Animal Brucellosis and Tuberculosis according to the records of supervision applied by the Institute of Agricultural and Forestry Defense of Espírito Santo state, Brazil, between 2008 and 2011.

\begin{tabular}{|c|c|c|c|c|}
\hline \multirow{2}{*}{ Observed items } & \multicolumn{2}{|c|}{ Compliant } & \multicolumn{2}{|c|}{ Non compliant } \\
\hline & n & $\%$ & n & $\%$ \\
\hline Computer & 60 & 95 & 3 & 5 \\
\hline Facsimile machine & 52 & 83 & 11 & 17 \\
\hline Living room with water point & 62 & 98 & 1 & 2 \\
\hline Refrigerator with freezer & 62 & 98 & 1 & 2 \\
\hline Automatic micropipetor of $30 \mathrm{~mL}$ or other volumes & 62 & 98 & 1 & 2 \\
\hline Source of indirect lighting & 59 & 94 & 4 & 6 \\
\hline Stopwatch & 62 & 98 & 0 & 0 \\
\hline Glass plate for seroagglutination & 62 & 98 & 1 & 2 \\
\hline Material for blood collecting & 62 & 98 & 1 & 2 \\
\hline Irons for marking vaccinated animals and positive reagents animals & 58 & 92 & 5 & 8 \\
\hline Heated room measured by thermometer & 31 & 49 & 32 & 51 \\
\hline Multidose syringes suitable for tuberculin of bovine (two) & 62 & 98 & 1 & 2 \\
\hline Specific cutimeter for tuberculin test & 62 & 98 & 1 & 2 \\
\hline Avian and bovine PPD tuberculin & 49 & 78 & 1 & 2 \\
\hline Equipment for trichotomy & 62 & 98 & 1 & 2 \\
\hline
\end{tabular}

Compliant: Regular status at the Institute of Agricultural and Forestry Defense of the Espírito Santo (IDAF), based on the Normative Instruction $\mathrm{n}^{\circ} 30$ of 2006 and the Technical Manual of PNCEBT (Brazil, 2006a; 2006b); Non compliant: Irregular situation in IDAF. 
to perform activities, but wore a wristwatch, and $13(21 \%)$ did not possess stockpiles of avian and bovine PPD tuberculins at the time of inspection, despite using these inputs for that was not considered as noncompliant.

It was found that most qualified professionals supervised (62.98\%) adopt the model of official certificates of vaccination and prescriptions for the purchase of vaccines (Table 3). This fact is important, since studies on the prevalence of bovine brucellosis in the PNCEBT demonstrated that well-structured and administered programs reach good levels of control, with significant reduction in prevalence (PoEsTer et al., 2009). For this structure, it is essential that professionals maintain considerable level of organization and standardization of procedures.

On the other hand, although the majority sends monthly reports $(42.33 \%)$ and forms $(62.98 \%)$ for the correct issuing of certificates of vaccination, it was found that most of the qualified professionals $(21.33 \%)$ delayed sending monthly reports of the vaccinations performed (Table 3). Indeed, noncompliance occurred due to the delay in sending and not specifically in completing the reports. This is interesting because it allows evaluating the quality of service, thus indicating the need for training to implement the correct procedures.

The delivery of reports of deadlines established is very important, since the state agencies for health protection responsible for the collection of data of vaccination and tests should take special care in these activities. This is because a collect closer to reality enables other works like that, besides favoring an adequate evaluation of the program (VALENTE et al., 2011).

In the present study, it was observed that $13(20 \%)$ of the qualified professionals do not maintain regular stocks of inputs (antigens and allergens-temperature +02 to $+08^{\circ} \mathrm{C}$ ) for the diagnosis of brucellosis and tuberculosis. However, the literature emphasizes that, for the control of brucellosis, health measures are based on two main focuses - diagnosis and vaccination -, for which it is possible to reduce or prevent exposure of animals to infectious agents and increase the resistance of livestock. Bovine brucellosis is endemic throughout the country, and the Brazilian historic shows that vaccination activities deserve special attention of the PNCEBT (Paulin; Ferreira Neto, 2002).
The tuberculin test is of great importance as a method of selection of animals that may represent risk to public health (Pinto et al., 2002), as well as to animal health, since the most significant source of infection for livestock is bovine or buffalo infected, and the main way to introduce tuberculosis in a herd is the purchase of infected animals (PACHECO et al., 2009). Monitoring is essential for the maintenance of a healthy herd; to improve the diagnosis, it is important that the service follow the actions of veterinarians in the field, where the tests are performed. Nevertheless, in this study, it was found that in Espírito Santo, between 2008 and 2011, it was not possible to follow the procedures in $60(95 \%)$ of the field inspections and in 42 (67\%) of the laboratory inspections, mainly due to difficulties in scheduling with the official service.

It was found that $51(80 \%)$ of the professionals record the results of tests satisfactorily (Table 4). Although not performed in this study, the details of types of the most common mistakes made by 12 (19\%) professionals, who do not report the results of the tests satisfactorily, are important because it would allow the adoption of the necessary improvements to the system of defense.

Regarding marking and euthanasia of positive animals, it was found that $21(33 \%)$ have some type of noncompliance (Table 4), and that $16(25 \%)$ of the total supervised had not yet registered reagent animals (positive).

Concerning the procedures for the certification of properties and the final opinion conducted by qualified veterinarians to serve on the PNCEBT, it was found that the majority, 61 (96.00\%), of the qualified professionals had not claims for certification of properties, mainly due to the lack of interest from producers. The low demand can be linked to high costs and low financial return associated with certification. It is important to highlight that joining the certification process is voluntary and it would be interesting to implement incentive mechanisms to producers to encourage the increase of preventive practices. Such initiatives should be developed in collaboration with all actors in the productive chain, mainly industry (BraziL, 2006b; VALENTE et al., 2011).

In the present study it was observed that in Espírito Santo, between the years 2008 and 2011, the disabling of one

Table 3. Procedures for vaccination of calves performed by veterinarians qualified to act on the National Programme for Control and Eradication of Animal Brucellosis and Tuberculosis according to the records of inspection applied by the Institute of Agricultural and Forestry Defense of the Espírito Santo state, Brazil, between 2008 and 2011.

\begin{tabular}{lcccc} 
& \multicolumn{2}{c}{ Compliant } & \multicolumn{2}{c}{ Non compliant } \\
\cline { 2 - 5 } Observed items & $\mathbf{n}$ & $\%$ & $\mathbf{n}$ & $\%$ \\
Referral of forms for emission of certificates of vaccination & 62 & 98 & 1 & 2 \\
\hline Official models of certificates of vaccination & 62 & 98 & 1 & 2 \\
\hline Official models of prescriptions to purchase vaccines & 62 & 98 & 1 & 2 \\
\hline Using vaccinators as support & 18 & 29 & 7 \\
\hline Correct marking of vaccinated animals & 58 & 92 & 5 & 11 \\
\hline Referral of monthly reports of vaccination & 42 & 67 & 21 & 33
\end{tabular}

Compliant: Regular status at the Institute of Agricultural and Forestry Defense of the Espírito Santo (IDAF), based on the Normative Instruction $\mathrm{n}^{\circ} 30$ of 2006 and the Technical Manual of PNCEBT (Brazil, 2006a; 2006b); Non compliant: Irregular situation in IDAF. 
Table 4. Procedures for the diagnosis of brucellosis and tuberculosis performed by veterinarians qualified to serve on the National Programme for Control and Eradication of Animal Brucellosis and Tuberculosis according to the records of supervisions applied by the Institute of Agricultural and Forestry Defense of Espírito Santo state, Brazil, between 2008 and 2011.

\begin{tabular}{lcccc} 
& \multicolumn{2}{c}{ Compliant } & \multicolumn{2}{c}{ Non compliant } \\
\cline { 2 - 4 } Observed Items & $\mathbf{n}$ & $\%$ & $\mathbf{n}$ & $\%$ \\
\hline Stocks of antigens and allergens in +2 to $+8^{\circ} \mathrm{C}$ temperature & 49 & 78 & 1 & 2 \\
\hline Procedures in laboratory & 19 & 30 & 2 & 3 \\
\hline Procedures in field & 2 & 3 & 1 & 12 \\
\hline Records of performed tests & 51 & 81 & 21 \\
\hline Marking of positive animals & 26 & 41 & 33 \\
\hline Procedures for euthanasia of positive animals & 26 & 41 & 21 & 33 \\
\hline Certificates of tests in official models & 63 & 100 & 0 & 0 \\
\hline Correct filling of the test's certificates & 53 & 84 & 10 & 16 \\
\hline Referral of reports & 43 & 68 & 20 & 32 \\
\hline Numbering of the certificates of the tests & 58 & 92 & 5 \\
\hline
\end{tabular}

Compliant: Regular status at the Institute of Agricultural and Forestry Defense of the Espírito Santo (IDAF), based on the Normative Instruction $n^{\circ} 30$ of 2006 and the Technical Manual of PNCEBT (Brazil, 2006a; 2006b); Non compliant: Irregular situation in IDAF.

professional was asked after a routine inspection by IDAF, after noticing the absence of the minimum infrastructure required and the occurrence of many procedural errors.

After the inspections, in most cases, 38 (60\%) recommendations were made by the official state agency to veterinarian vaccinators, mainly related to the importance of education of the professionals regarding the need to keep current addresses, filling and referral monthly reports of calves vaccination and performing of tests, in addition to the establishing of alternative ways for official communication of positive cases of tuberculosis and brucellosis, routine maintenance of inspections to verify the infrastructure and the performing of tests and achievement of registration of vaccinators by the IDAF.

\section{CONCLUSIONS}

All the supervised professionals are regularly registered in CRMV-ES, however there are cases of pending issues in the registry to perform the vaccinations against brucellosis.
The majority adopts the official model of vaccination certificates and examinations and prescriptions for the purchase of vaccines, yet there is a significant delay in the submission of reports of actions, and many professionals reported a lack of demand for certification of properties. As for the registration of test results, there is the need for adequacy, as well as the verification of field procedures.

It was observed that most professionals maintain the infrastructure for performing tests for brucellosis and tuberculosis. Nevertheless, in most inspections, it was necessary to educate vaccinators, especially regarding the importance of maintaining records, the examinations and dispatch of the results.

\section{ACKNOWLEDGMENTS}

This work was financially supported by Ministério da Agricultura, Pecuária e Abastecimento and Conselho Nacional de Desenvolvimento Cientifico e Tecnologico (research scholarship to C.M.B.M.R.), Brazil.

| | | | | | | | | | | | | | | | | | | | | | | | | | | | | | | | | | | | | | | | | | | | | | | | | | | | | | | | | | | | | | | | | | | | | | | | | | | | | | | | | | | | | | | | | | | | | | | | | | | | | | | | | | | | | | | | | | | | | | | | | | | | | | | | | | | | | | | | | | | | | | | | | | | | | | | | | | | | | | | | | | | | | | | | | | | | | | | | | | | | | | | | | | | | | | | | | | | | | | | | | | | | | | | | | | |

\section{REFERENCES}

ARAÚJO, H.S.; SABBAG, O.J.; LIMA, B.T.M.; ANDRIGHETTO, C.; RUIZ, U.S. Aspectos econômicos da produção de bovinos de corte. Pesquisa Agropecuária Tropical, v.42, n.1, p.8289, 2012. Disponível em: <http://www.revistas.ufg.br/ index.php/pat/article/view/13840/10449>. Acesso em: 25 mar. 2013.

BRASIL. Instrução Normativa 6, de 8 de janeiro de 2004. Aprova o regulamento técnico do Programa Nacional de Controle e Erradicação da Brucelose e Tuberculose Animal. Brasília: Ministério da Agricultura, Pecuária e Abastecimento - MAPA, 2004. Diário Oficial da União, seção 1, p. 6-10.

BRASIL. Instrução Normativa 30, de 7 de junho de 2006. Estabelece as normas de habilitação de médicos veterinários que atuam no setor privado, para fins de execução de atividades previstas no Regulamento Técnico do Programa Nacional de Controle e Erradicação da Brucelose e da Tuberculose Animal - PNCEBT. Brasília: Ministério de Agricultura, Pecuária e Abastecimento MAPA, 2006a. Diário Oficial da União, seção 1, p.5. 
BRASIL. Programa Nacional de Controle e Erradicação da Brucelose e da Tuberculose Animal (PNCEBT) - Manual Técnico. Brasília: Ministério de Agricultura, Pecuária e Abastecimento - MAPA, 2006b. 184p.

OIE - The World Organisation for Animal Health. Our missions. Available in: <http://www.oie.int/about-us/our-missions/>. Accessed: 25 Aug. 2012.

PACHECO, A.A.; HAMZĖ, A L.; RODRIGUES, C.A.; MEDEIROS, E.S.; FAVARO, M.R.; MELÂO, M.H.; FILADELPHO, A.L.; ZAPPA, V. Controle da tuberculose bovina. Revista Científica Eletrônica de Medicina Veterinária, v.7, n.12, s.p., 2009. Disponível em: <http://faef.revista.inf.br/imagens_arquivos/arquivos_destaque/ ixvKvaUf5pofMTg_2013-6-19-16-6-52.pdf>. Acesso em: 25 nov. 2010.

PAULIN, L.M.; FERREIRA NETO, J.S. A experiência brasileira no combate à brucelose bovina. Arquivos do Instituto Biológico, v.69, n.2, p.105-112, 2002. Disponível em: <http://www. biologico.sp.gov.br/docs/arq/V69_2/paulin.pdf>. Acesso em: 26 nov. 2010.

PINTO, P.S.A.; FARIA, J.E.; VILORIA, M.I.V.; BEVILACQUA, P.D. Exame microbiológico da tuberculose como subsídio à inspeção post-mortem de bovinos. Revista Brasileira de Saúde e Produção Animal, v.3, n.1, p.10-15, 2002. Disponível em: <http://revistas. ufba.br/index.php/rbspa/article/view/615/359>. Acesso em: 25 nov. 2010.

POESTER, F.; FIGUEIREDO, V.C.F.; LÔBO, J.R., GONÇALVES, V.S.P.; LAGE, A.P.; ROXO, E.; MOTA, P.M.P.C., MÜLLER, E.E.; FERREIRA NETO, J.S. Estudos de prevalência da brucelose bovina no âmbito do Programa Nacional de Controle e Erradicação de Brucelose e Tuberculose: Introdução. Arquivos Brasileiros de Medicina Veterinária e Zootecnia, v.61, p.1-5, 2009. Suplemento 1. Disponível em: <http://www.scielo.br/pdf/abmvz/v61s1/a01v61s1.pdf>. Acesso em: 25 nov. 2010.

RUBIN, L.S.; ILHA, A.S.; WAQUIL, P. D. O comércio potencial brasileiro de carne bovina no contexto de integração regional. Revista de Economia e Sociologia Rural, v.46, n.4, p.1067-1094, 2008. Disponível em: <http://www.scielo.br/pdf/resr/v46n4/ v46n4a07.pdf >. Acesso em: 25 nov. 2010.

VALENTE, L.C.M.; VALE, S.M.L.R.; BRAGA, M. J. Determinantes do Uso de Medidas Sanitárias de Controle da Brucelose e Tuberculose Bovinas. Revista de Economia e Sociologia Rural, v.49, n. 1, p.215232, 2011 . Disponível em: <http://www.scielo.br/pdf/resr/ v49n1/a09v49n1.pdf >. Acesso: 25 nov. 2011. 